\title{
Phenolic Contents, Metal Contaminations, Antioxidant and Antimicrobial Properties of Five Medicinal Dietary Spices
}

\author{
Muhammad Riaz ${ }^{1}$, Saima Manzoor, Sadia Naseem ${ }^{1}$, Sehrish Saddiq ${ }^{1}$ \\ and Rehana Rashid ${ }^{2}$ \\ ${ }^{1}$ Department of Chemistry, University of AJK, Muzaffarabad, Pakistan \\ ${ }^{2}$ Department of Chemistry, COMSATS Institute of Information Technology, Abbottabad, KPK, Pakistan
}

(Received: November 01, 2017; Accepted: January 10, 2018; Published: January 30, 2018)

\begin{abstract}
Five exotic dietary and medicinal spices (Trachyspermum ammi, Curcuma longa, Piper nigrum (Black pepper, Anacardium occidentate, Syzygium aromaticum) were studied for their metal contaminations, phenolic contents, antioxidant and antibacterial properties. White pepper contains maximum phenolic contents and black pepper showed higher antioxidant potential. Clove showed maximum antimicrobial potential $(25-30 \mathrm{~mm})$ against Escherichia coli and Staphylococcus aureus (18-21 mm). White pepper contained maximum phenolic contents. Estimation of metal contamination in spices indicated that $\mathrm{K}, \mathrm{Ca}, \mathrm{Mg}$, $\mathrm{Cu}$, Co, As, Hg, Mo were above the standard permissible limits (SPL), Cr, Ni and Cd within standard permissible limits, whereas, $\mathrm{Fe}, \mathrm{Zn}, \mathrm{Mn}$ and $\mathrm{Pb}$ were below standard permissible limits.
\end{abstract}

Key words: Antioxidant, Antimicrobial, Metal Contaminations, Phenolic Contents, Dietary Spices.

\section{Introduction}

Exotic medicinal spices are essential flavoring component of our food and possess unmatched medicinal properties thus are rich reservoirs for potent drugs. Research advancements during the previous century have rewarded us with numerous natural products based molecular drugs to treat diseases. For example, turmeric powder is a famous and very old spice in Asian culture, has proved its miraculous curative properties against various diseases. Its natural products (curcumin, tumerone, atlantone, zingiberone) have been found potent against cancer and several infections (Sporn and Suh 2002). Many of these spices have proven effective preemptive herbal treatment through diet. These exotic spices are treasures for the modern molecular drug discovery as well as preemptive herbal treatment. However, explosion of industrialization and manufacturing has threatened everything in our ecosystem and that essentially include metal contamination these dietary spices.
Trachyspermum ammi (family: Apiaceae, common name: Ajwain) is widely used for curing various diseases in both humans and animals. A number of medicinal and therapeutic properties have been ascribed to its various parts. It is an important remedial agent for flatulence, atonic dyspepsia, and diarrhea (Ashraf and Orooj 2006). Seeds of ajwain are bitter, pungent and act as anthelmintic, carminative, laxative and stomachic. It also cures abdominal tumors, abdominal pains and piles (Krishnamoorthy and Madalageri 1999, Joshi 2000). Curcuma longa (family: Zingiberaceae, local name: turmeric) is a popular medicinal and aromatic plant with multiple uses. Turmeric is known as the "golden spice" as well as the "spice of life." It has been used in Pakistan and India as a medicinal plant and held sacred from time immemorial. This plant is cultivated in all parts of India (Kapoor 2000). Curcumin obtained from the turmeric rhizome (Curcuma longa) possess skin protective ability from harmful UVinduced effects by displaying antimutagen,

Correspondence to: Muhammad Riaz, Department of Chemistry, University of AJK, Muzaffarabad, Pakistan E-mail: mriazm1@yahoo.com, Phone: (92)334 9270235 
antioxidant, anti-inflammatory and anti-carcinogenic properties. Piper nigrum L. is found throughout Pakistan and India. Black pepper is a plant of humid tropics requiring high rainfall and humidity (Ahmad, Fazal et al. 2012). The phytochemical investigations of $P$. nigrum revealed that it contains variety of phytochemicals such as phenolic derivatives, flavonoids, alkaloids, amides and steroids, lignans, neolignans, terpenes, chalcones and many other compounds. Its piperine increases bioavailability of many drugs and nutrients by inhibiting various metabolizing enzymes. Piper nigrum $\mathrm{L}$ and its active constituent "piperine" exhibit diverse pharmacological activities like antibacterial, antiviral, anticancer and hepatoprotective activity(Araujo and Leon 2001). Anacardium occidentale (family: Anacardiaceae, common name: cashew) juice is used as diuretic, in treatment of kidney diseases and cholera. The shell oil is used as mild purgative, for expulsion of hookworms, for cracks in feet, warts and corns. The leaves and seed coat of cashew tree has not been used as extensively as compared to many medicinal herbs or trees (Chan, Baba et al. 2017). Syzygium aromaticum (family: Myrtaceae, common name: clove or long), a commonly used spice and flavourant (Nutman and Roberts 1971, Van Wyk, Roux et al. 2004). The tree is indigenous to the Molucca Islands, but has spread over many countries where it is now commercially cultivated. It is used as antioxidant, antibacterial, antitumor and antiviral agent believed to be due to its two major constituents of clove, biflorinand casuarictin (Table 1).

Pakistan is major producer, user and supplier of many exotic medicinal spices among other countries. There are significant variations at each location for example, in climatic conditions, environmental conditions and industrial wastes. Therefore, we designed and undertook to investigate these five selected medicinal spices for their phenolic contents, metal contamination, antioxidant potencies and antimicrobial properties.

Table 1. Botanical Name, Common Name, parts of plant used and medicinal importance of selected spices.

\begin{tabular}{|c|c|c|c|}
\hline$\#$ & $\begin{array}{l}\text { Botanical Name } \\
\text { (Common Name) }\end{array}$ & Part used & Medicinal Uses \\
\hline 1 & $\begin{array}{l}\text { Trachyspermum ammi } \\
\text { (Ajwain) }\end{array}$ & Seed & $\begin{array}{l}\text { It is an important remedial agent for flatulence, atonic dyspepsia, and } \\
\text { diarrhea (Ashraf and Orooj, 2006). The seed of ajwain is bitter, pungent, } \\
\text { and it acts as anthelmintic and stomachic. It also cures abdominal } \\
\text { tumors, abdominal pains, and piles. }\end{array}$ \\
\hline 2 & $\begin{array}{l}\text { Curcuma longa } \\
\text { (Turmeric) }\end{array}$ & rhizome & $\begin{array}{l}\text { It is used to treat urinary, respiratory and liver diseases. It is also used as } \\
\text { anticancer agent (Choi, Yan et al., 2010); Araujo and Leon, 2001). }\end{array}$ \\
\hline 3 & $\begin{array}{l}\text { Piper nigrum (Black } \\
\text { pepper) }\end{array}$ & Seed & $\begin{array}{l}\text { Piper nigrumL and its active constituent "Piperine”'exhibits diverse } \\
\text { pharmacological activities like antihypertensive, antiplatelet, } \\
\text { antioxidant, antitumor, antiasthmatics, analgesic, antiinflammatory, } \\
\text { antidiarrheal, , antibacterial, antifungal, hepato-protective, insecticidal } \\
\text { and larvicidal activities etc. (Araujo and Leon, 2001). }\end{array}$ \\
\hline 4 & $\begin{array}{l}\text { Anacardium } \\
\text { occidentale (Cashew) }\end{array}$ & Seed & $\begin{array}{l}\text { Juice of cashew is used as diuretic, in treatment of kidney diseases and } \\
\text { cholera. The shell oil is used as mild purgative, for expulsion of } \\
\text { hookworms, for cracks in feet, warts and corns. The leaves and seed coat } \\
\text { of cashew tree has not been used as extensively as compared to many } \\
\text { medicinal herbs or trees (Chan, et al., 2017). }\end{array}$ \\
\hline 5 & $\begin{array}{l}\text { Syzygium aromaticum } \\
\text { (Clove) }\end{array}$ & Seed & $\begin{array}{l}\text { It is used to treat many diseases caused by viruses and bacteria. It is also } \\
\text { used to treat tumor (Nutman and Roberts, 1971; Van et al., 2004). }\end{array}$ \\
\hline
\end{tabular}




\section{Materials and Methods}

Plant material collection: During research, different spices were selected and purchased from local spice shop. The identification of each spice was verified by Professor Dr. Muhammad Qayyum Khan (taxonomist) wherein a voucher specimen has been kept as UAJK-BOT-17-23. All spices were grinded into fine powder.

Preparation of extracts: $100 \mathrm{mg}$ of each spice, in powder form, was soaked in methanol for 20 days. We designed to study their antioxidant, antimicrobial activities, metal contaminations and phenolic contents by using these crude or methanolic extract.

Sample preparation for antioxidant activities: 10 mg of dried methanolic extract of each spice's powder was dissolved in $10 \mathrm{ml}$ of methanol. ABTS radical cation $\left(\mathrm{ABTS}^{+*}\right)$ decolorization assay method was used to evaluate the antioxidant activities of each methanolic extract of these spices.
ABTS $^{+\bullet}$ decolorization assay for antioxidant activities: The free radical scavenging capacity of each spice's extract was studied using the ABTS radical cation decolorization assay (Pellegrini et al. 1999), which is based on the reduction of $\mathrm{ABTS}^{+}$ radicals by antioxidants of the plant extracts under study. Stock solution was prepared by dissolving 64.8 $\mathrm{mg}$ of $\mathrm{ABTS}^{+\cdot}$ and $33.57 \mathrm{mg}$ of potassium per sulphate in water and allowing the mixture to stand in the dark at room temperature for 12-16 hrs before use. $\mathrm{ABTS}^{+\bullet}$ solution was diluted with water until its absorbance reached to (2.00) at $540 \mathrm{~nm}$. The activity was performed with methanolic extracts by making standard, blank and a sample solution for each spice. All solutions were used within the same day of preparation and all determinations were carried out in triplicate. The percentage of inhibition of $\mathrm{ABTS}^{+*}$ (Table 2) was calculated using following formula.

$\% R S C=\left[A_{\text {Ocontrol }-} A_{i \text { sample }}\right] / A_{\text {control }} \times 100$

Wherein $A_{o}$ is the absorbance of the control and $A_{i}$ is the absorbance of the sample.

Table 2. Protocol for ABTS $^{+\bullet}$ Assay.

\begin{tabular}{llll}
\hline Solution & ABTS*+ $(\mathrm{ml})$ & Distilled water $(\mathrm{ml})$ & Sample (microliter) \\
\hline Standard & 1 & 2 & - \\
Sample & 1 & $900,800 \& 700$ & $100,200,300$ \\
Blank & - & $2 \mathrm{ml}+900,800 \& 700$ & $100,200,300$ \\
\hline
\end{tabular}

Preparation of sample for antimicrobial activities: To evaluate antimicrobial activity of these spices, sample solutions were prepared by dissolving $20 \mathrm{mg}$ of each dried methanolic extract in $1 \mathrm{ml}$ of methanol separately and air tight Eppendorf tubes were used to prevent contamination and kept for four days to ensure maximum solubility.

Test microorganisms: Two human clinical bacterial pathogens were selected, Escherichia coli and Staphylococcus aureus. These pathological strains were taken from Microbiological Laboratory of H.H. Sheikh Khalifa Bin Zayed Al-Nahyan Hospital of Azad Jammu and Kashmir, Muzaffarabad, Pakistan.
Antimicrobial assay: Antimicrobial activities were assessed by the Agar-well diffusion method for methanolic extracts of all spices (Balouiri et al. 2016). Nutrient agar and nutrient broth media were used for bacterial culture. Microorganisms were activated by inoculating a loop full of strain in $50 \mathrm{ml}$ (for each pathogen) of nutrient broth medium and incubated at $37^{\circ} \mathrm{C}$ on a rotary shaker for 24 hours. The overnight culture was mixed with freshly prepared nutrient agar medium (NAM) at $45^{\circ} \mathrm{C}$ and was poured into the sterilized petri dishes. All petri dishes were kept at room temperature in laminar flow for solidification. The prepared $7 \mathrm{~mm}$ discs from whatman paper were dipped into prepared methanolic solution of respective spice and placed on agar media 
in petri plates, kept in $37^{\circ} \mathrm{C}$ for $24-48 \mathrm{~h}$. Antibiotic streptomycin was used as a control. Microbial growth was determined by measuring the diameter of zone of inhibition after $24 \mathrm{~h}$ in millimeter. Diameter of the clear zones (if greater than $7 \mathrm{~mm}$ ) around each disc was measured with the help of scale. Results of sensitivity tests were expressed as (0) for no sensitivity, (7-10 mm) for low sensitivity, (11-20mm) for moderate sensitivity and (>20mm) for high sensitivity.

Determination of total phenolic contents: Sample solutions were prepared by dissolving $10 \mathrm{mg}$ of dried methanolic extract in $10 \mathrm{ml}$ of methanol Total phenolic contents of each extract were determined by method described by Singleton et al. by using FolinCiocalteu method (Simpson, 1982) and gallic acid was used as standard. 1-10 mg of gallic acid was dissolved in distilled water (10 different solutions) in order to obtain standard values. About $7.5 \%$ sodium carbonate solution $(7.5 \mathrm{~g}$ in $100 \mathrm{ml}$ distilled water), $10 \%$ Folin-Ciocalteu reagent solution $(10 \mathrm{ml}$ in $100 \mathrm{ml}$ water) were prepared. Sample and blank solutions were prepared of each spice to check total phenolic contents. Sample solution was prepared by addition of $0.5 \mathrm{ml}$ of methanolic extract, $0.5 \mathrm{ml}$ of FolinCiocalteu reagent and $2.5 \mathrm{ml}$ of sodium carbonate for neutralization (for each spice), while blank was prepared by the same method as sample but instead of methanolic extract only distilled water was added Table 3). After incubation for $1 \mathrm{~h}$ at room temperature, absorbance was measured at $765 \mathrm{~nm}$. All determinations were carried out in triplicates.

Table 3. Phenolic contents.

\begin{tabular}{ccccc}
\hline Solution & Methanolic extracts $(\mathrm{ml})$ & Folin-ciocalteu $(\mathrm{ml})$ & $\mathrm{Na}_{2} \mathrm{CO}_{3}(\mathrm{ml})$ & Dist. water $(\mathrm{ml})$ \\
\hline Sample & 0.5 & 0.5 & 2.5 & - \\
Blank & - & 0.5 & 2.5 & 0.5 \\
\hline
\end{tabular}

Sample preparation for the estimation of metal contamination: Each dried spice was ground into the powder from and $1 \mathrm{mg}$ of each was taken in a pyrex glass beaker. $6 \mathrm{ml}$ of concentrated nitric acid $\left(\mathrm{HNO}_{3}\right)$ and hydrogen peroxide $\left(\mathrm{H}_{2} \mathrm{O}_{2}\right)$ were added (in 2:1 $\mathrm{V} / \mathrm{V}$ ) and mixture was stirred slowly at room temperature. The glass beaker was covered with petri dish and heated at $70^{\circ} \mathrm{C}$ for three hours with continuous addition of $\mathrm{HNO}_{3}$ and $\mathrm{H}_{2} \mathrm{O}_{2}$ along with continuous heating at $80^{\circ} \mathrm{C}$ till a clear solution was obtained. The excess of acid was evaporated and a semi dry mass was obtained which was filtered with aqua-regia (mixture of nitric and sulphuric acid in a ratio 1:3) in a volumetric flask to make the volume of solution up to $30 \mathrm{ml}$.

Specification of AAS (Atomic Absorption Spectroscopy): Operating parameters of Atomic Absorption Spectrophotometer (AAS) AAnalyst ${ }^{700}$ was used in the analysis of trace metals using respective wavelength in the range of $190-900 \mathrm{~nm}$, diffraction grating: 1800 lines/mm blazed at $236 \mathrm{~nm}$ and $597 \mathrm{~nm}$, grating area: $64 \times 72 \mathrm{~mm}$, reciprocal linear dispersion: $1.6 \mathrm{~nm} / \mathrm{mm}$ (nominal), focal length: $267 \mathrm{~mm}$, spectral bandwidths: 0.2, 0.7 and $2.0 \mathrm{~nm}$, dual height, motorized slit drive for automatic slit selection with wide-range segmented solid-state detector. AAnalyst ${ }^{700}$ used winlab 32 program to automatically calculate the mean of three reading of three sample of each spice for each metal.

\section{Results and Discussion}

Antioxidant activities: Percentage radical scavenger activity (\%RSC) was calculated out from which $\mathrm{IC}_{50}$ values were calculated out of which is half maximal inhibitory concentration which is a measure to check the effectiveness of a substance to inhabit a chemical or biochemical process. IC $_{50}$ values are calculated out which are presented graphical form in Figure 1. Maximum antioxidant activity was estimated out for black pepper with an $\mathrm{IC}_{50}$ value of 1.46 unit, while turmeric showed minimum antioxidant potential with an $\mathrm{IC}_{50}$ value of 
9.77 unit. Moderate or average antioxidant potential was recorded for clove (Table 3).

Antimicrobial activities against E. coli and S. aureus: Ajwain and black pepper have showed no sensitivity against. Turmeric and cashew showed marginal sensitivity against E. coli. Clove showed highest antimicrobial potential against E. coli. Ajwain, black pepper and cashew showed no sensitivity against $S$. aureus. Turmeric showed moderate sensitivity against $S$. aureus. Clove showed highest antimicrobial potential against $S$. aureus (Figures 1-3).

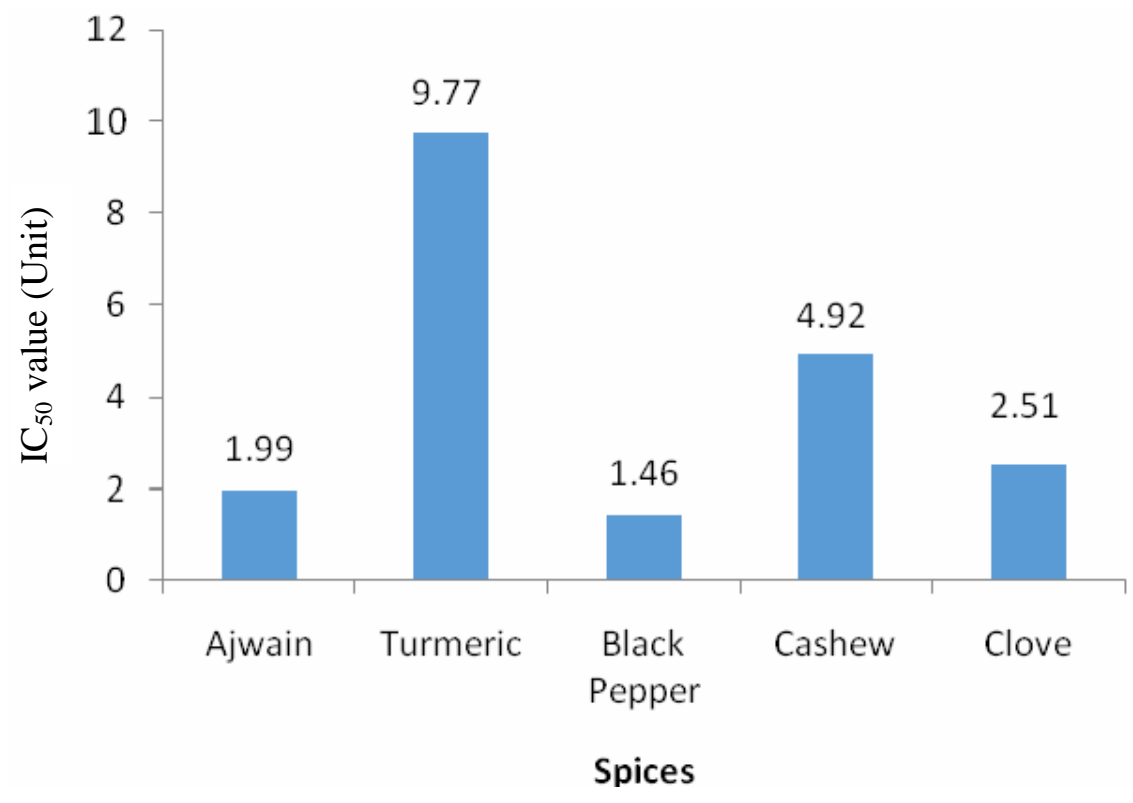

Figure 1. Antioxidant activities of five dietary spices.

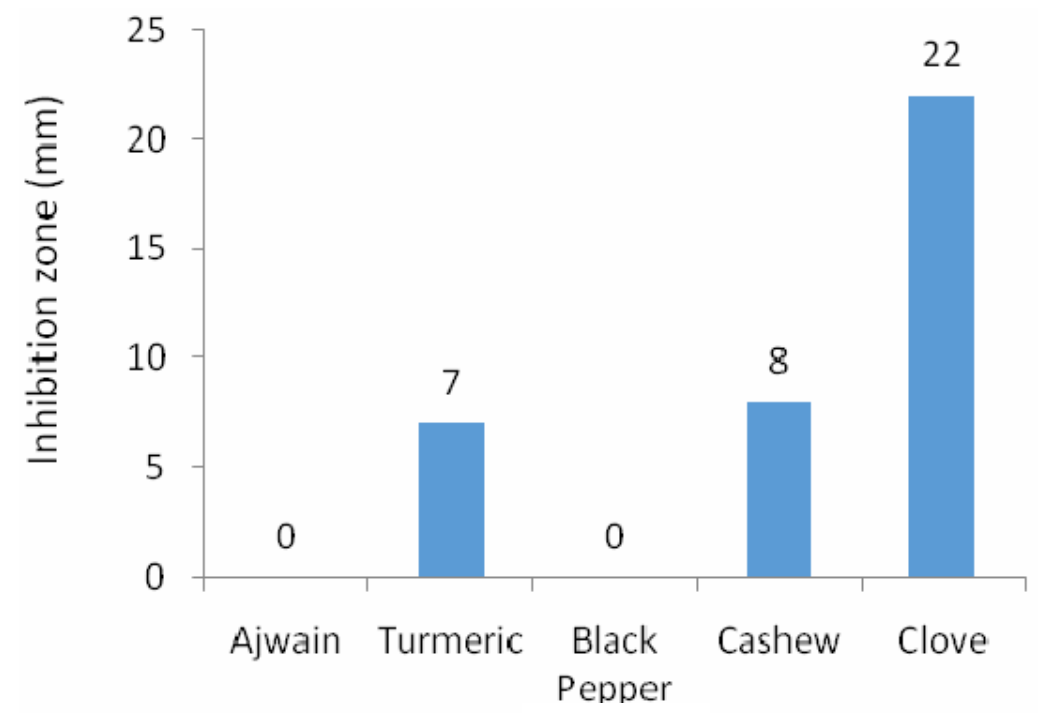

Figure 2. Antimicrobial activities against E. coli. 


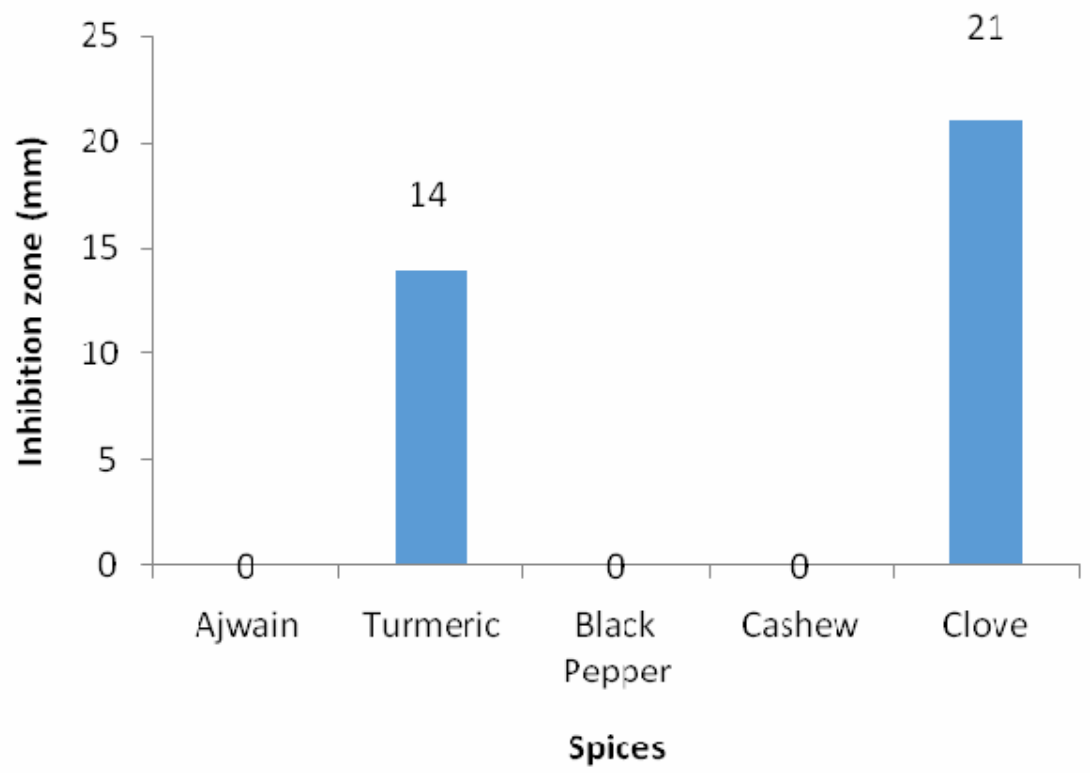

Figure 3. Antimicrobial activities against $S$. aureus.

Table 2. Antioxidant activities.

\begin{tabular}{llccc}
\hline$\#$ & Spices & Conc. Used $(\mu \mathrm{l})$ & Max. Absorption (\%) & mg GAE/g \\
\hline 01 & Ajwain & 2.5 & 3.27 & 4 \\
02 & Turmeric & 2.5 & 3.667 & 1.5 \\
03 & Black Pepper & 2.5 & 2.176 & 4.8 \\
4 & Cashew & 2.5 & 2.204 & 3 \\
05 & Cloves & 2.5 & 3.667 & 3.4 \\
\hline
\end{tabular}

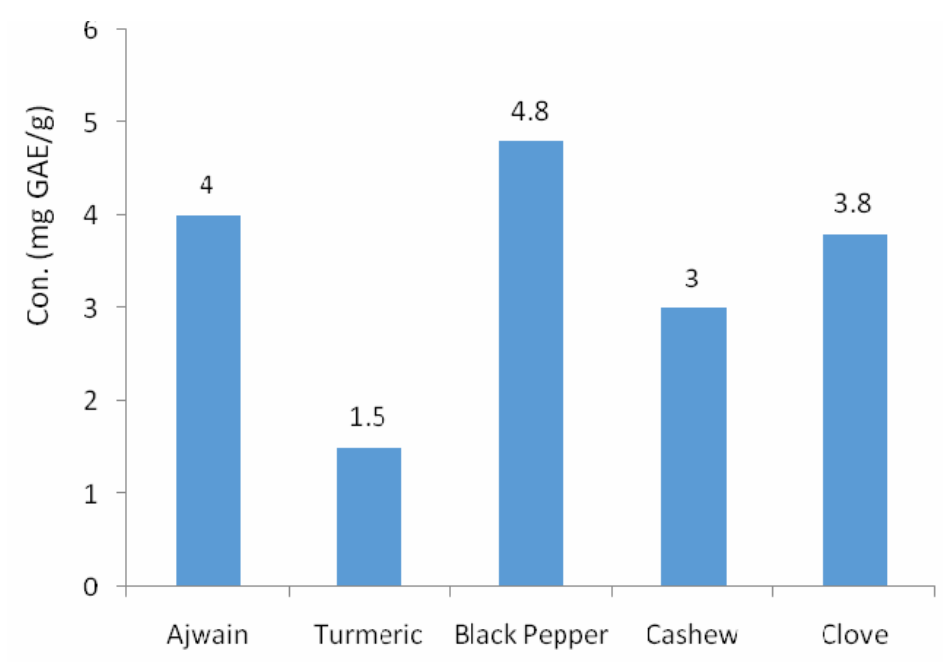

Figure 4. Total phenolic contents. 
Total phenolic contents: Phenolic contents were estimated out by using Folin-Ciocalteu method. Maximum phenolic contents were determined for black pepper and ajwain with a value of 4.8 and 4 unit respectively and minimum for turmeric i.e 1.5. Clove and cashew have shown average concentration of phenolic contents (Figure 4).

Estimation of toxic metal contamination: The present study reports the contents of both essential and toxic metals, namely, $\mathrm{K}, \mathrm{Fe}, \mathrm{Ca}, \mathrm{Mg}, \mathrm{Fe}, \mathrm{Zn}, \mathrm{Cu}$, $\mathrm{Co}, \mathrm{Cr}, \mathrm{Mn}, \mathrm{Ni}, \mathrm{Cd}, \mathrm{Pb}$, As and Mo determined in selected spices collected from Muzaffarabad, Azad Jammu and Kashmir. The observed concentrations of
K, Fe, Ca, Mg, Hg, Zn, Cu, Co, Cr, Mn, Ni, Cd, Pb, As and Mo in the spices were compared with the standard permissible limits by the FAO/WHO to assess the levels of food contamination and to evaluate their impact on the health.

Mean value of each metal content in each spices has been shown in tables 4,5 and 6 (Note: wavelengths of each metal estimation are $\mathrm{K}=766.5$ $\mathrm{nm}, \mathrm{Mg}=285.2 \mathrm{~nm}, \mathrm{Ca}=422.7 \mathrm{~nm}, \mathrm{Cr}=357.9 \mathrm{~nm}$, $\mathrm{Mn}=279.5 \mathrm{~nm}, \mathrm{Fe}=248.3 \mathrm{~nm} \mathrm{Co}=240.7 \mathrm{~nm}, \mathrm{Ni}=$ $232.0 \mathrm{~nm}, \mathrm{Cu}=324.8 \mathrm{~nm}, \mathrm{Zn}=213.9 \mathrm{~nm}$, As $=193.7$ $\mathrm{nm}, \mathrm{Mo}=313.3 \mathrm{~nm}, \mathrm{Cd}=228.8, \mathrm{Hg}=253.7 \mathrm{~nm}$ and $\mathrm{Pb}=283.83 \mathrm{~nm})$.

Table 4. Estimation of metal contaminations $(\mu \mathrm{g} / \mathrm{ml})$.

$\begin{array}{llllllllllllllll}\text { \# } & \text { Plant name } & \mathrm{Mg} & \mathrm{K} & \mathrm{Ca} & \mathrm{Cr} & \mathrm{Co} & \mathrm{Ni} & \mathrm{Cu} & \mathrm{Fe} & \mathrm{Zn} & \mathrm{As} & \mathrm{Mo} & \mathrm{Cd} & \mathrm{Hg} & \mathrm{Pb} \\ 1 & \text { Ajwain } & 0 & 10.73 & 0 & 0.284 & 0.227 & 0.308 & 0.326 & 1.327 & 0.524 & 0 & 2.867 & 0.045 & 44.55 & 0.581 \\ 2 & \text { Turmeric } & 0 & 2.909 & 0 & 0.505 & 0.259 & 0.345 & 0.296 & 3.045 & 0.738 & 0 & 3.006 & 0.039 & 37.46 & 0.6 \\ 3 & \text { Black pepper } & 0 & 100.5 & 0 & 0.323 & 0.257 & 0.364 & 0.299 & 1.709 & 0.782 & 0 & 3.047 & 0.025 & 32.35 & 0.604 \\ 4 & \text { Cashew } & 7.52 & 16.08 & 0 & 0.246 & 0.316 & 0.317 & 0.397 & 0.882 & 0.77 & 0 & 3.303 & 0.061 & 26.22 & 0.933 \\ 5 & \text { Cloves } & 0 & 100.2 & 0 & 0.302 & 0.226 & 0.321 & 0.288 & 1.243 & 0.321 & 0 & 3.361 & 0.056 & 25.61 & 0.882\end{array}$

Table 5. Essential or soft metal concentration $(\mu \mathrm{g} / \mathrm{ml})$.

\begin{tabular}{lccccccccccccccc}
\hline Spices & $\mathrm{Mg}$ & $\mathrm{K}$ & $\mathrm{Ca}$ & $\mathrm{Cr}$ & $\mathrm{Mn}$ & $\mathrm{Fe}$ & $\mathrm{Co}$ & $\mathrm{Ni}$ & $\mathrm{Cu}$ & $\mathrm{Zn}$ & $\mathrm{As}$ & $\mathrm{Mo}$ & $\mathrm{Cd}$ & $\mathrm{Hg}$ & $\mathrm{Pb}$ \\
\hline Clove & 0 & 100 & 0 & 0.3 & 0 & 1.24 & 0.22 & 0.32 & 0.28 & 0.32 & -9.32 & 3.36 & 0.05 & 25.61 & 0.88 \\
Cashew & 7.52 & 16 & 20.5 & 0.24 & 0.01 & 0.88 & 0.31 & 0.31 & 0.39 & 0.77 & -4.39 & 3.3 & 0.06 & 26.22 & 0.93 \\
Black & 0 & 100 & 0 & 0.32 & 0.06 & 1.7 & 0.25 & 0.36 & 0.29 & 0.78 & -8.18 & 3 & 0.02 & 32.35 & 0.6 \\
pepper & & & & & & & & & & & & & & & \\
Turmeric & 0 & 2.9 & 0 & 0.5 & 0.01 & 3.04 & 0.25 & 0.34 & 0.29 & 0.73 & -9.41 & 3 & 0.03 & 37.46 & 0.6 \\
Ajwain & 0 & 10.7 & 0 & 0.28 & 0.01 & 1.32 & 0.22 & 0.3 & 0.32 & 0.52 & -5.24 & 2.86 & 0.04 & 44.55 & 0.58 \\
\hline
\end{tabular}

Table 6. Toxic metal concentration $(\mu \mathrm{g} / \mathrm{ml})$.

\begin{tabular}{lccccc}
\hline Spices & As & Mo & Cd & Hg & Pb \\
\hline Ginger & -5.281 & 2.75 & 0.05 & 48.85 & 0.59 \\
Coriander & -1.7 & 2.64 & 0.03 & 56.6 & 0.6 \\
White pepper & 0.042 & 2.36 & 0.04 & 66.45 & 0.44 \\
Cumin & 3.849 & 2.38 & 0.02 & 75.22 & 1.17 \\
Poppy & 0.773 & 2.29 & 0.34 & 43.07 & 1.25 \\
\hline
\end{tabular}


This study indicated that $\mathrm{K}, \mathrm{Ca}, \mathrm{Mg}, \mathrm{Cu}, \mathrm{Co}$, As, $\mathrm{Hg}$, Mo are above standard permissible limits, $\mathrm{Cr}, \mathrm{Ni}$ and $\mathrm{Cd}$ are within standard permissible limits whereas, $\mathrm{Fe}, \mathrm{Zn}, \mathrm{Mn}$ and $\mathrm{Pb}$ are below standard permissible limits (Tables 5,6,7). These studies should be used as important guidelines for the producers, traders and regulatory authorities. Most of these spices are found to be safe for health with reference of metals but in case of $\mathrm{K}, \mathrm{Ca}, \mathrm{Mg}, \mathrm{Cu}, \mathrm{Co}$, As, Hg, Mo metals, the contaminations are above standard permissible limits therefore, serious measures are required to be taken.

\section{References}

Ahmad, N. H., Fazal, B. H., Abbasi, S., Farooq, M., Ali and M. A. Khan. 2012. Biological role of Piper nigrum L.(Black pepper): A review. Asian Pacific J. Tropical Biomedicine 2, S1945-S1953.

Araujo, C. and L. Leon 2001. Biological activities of Curcuma longa L. Memórias do Instituto Oswaldo Cruz 96, 723-728.

Ashraf, M. and A. Orooj 2006. Salt stress effects on growth, ion accumulation and seed oil concentration in an arid zone traditional medicinal plant ajwain (Trachyspermum ammi [L.] Sprague). J. Arid Environments 64, 209-220.

Balouiri, M. M., Sadiki. and S. K. Ibnsouda. 2016. Methods for in vitro evaluating antimicrobial activity: A review. J. Pharm. Analysis 6, 71-79.

Chan, E. W. C. S., Baba, H. T., Chan, M., Kainuma, T., Inoue and S. K. Wong 2017. Ulam herbs: A review on the medicinal properties of Anacardium occidentale and Barringtonia racemosa. J. Applied Pharm. Sci.7, 241-247.
Choi, Y.H., G.H. Yan., O. H. Chai. and C. H. Song 2010. Inhibitory effects of curcumin on passive cutaneous anaphylactoid response and compound 48/80-induced mast cell activation. Anatomy \& Cell Biology 43, 3643.

Joshi, S. G. 2000. Medicinal plants, Oxford and IBH publishing.

Kapoor, L. 2000. Handbook of Ayurvedic medicinal plants: Herbal reference library, CRC press.

Krishnamoorthy, V. and M. Madalageri 1999. Bishop weed (Trachyspermum ammi): an essential crop for north Karnatka. J. Medi. and Aromatic Plant Sci.21, 996998.

Nutman, F. and F. Roberts 1971. The clove industry and the diseases of the clove tree. PANS Pest Articles \& News Summaries 17, 147-165.

Re, R., N. Pellegrini., A. Proteggente., A. Pannala., M. Yang and C. Rice-Evans 1999. Antioxidant activity applying an improved ABTS radical cation decolorization assay. Free Radical Biology Medi. 26, 1231-1237.

Simpson, R. 1982. Factors affecting oxidative browning of white wine. Vitis 213, 233-239.

Sporn, M. B. and N. Suh 2002. Chemoprevention: an essential approach to controlling cancer. Nature Reviews Cancer 2, 537-543.

Van Wyk, M., J. Roux., I. Barnes., B. D. Wingfield., E. C. Liew., B. Assa., B. A. Summerell and M. J. Wingfield 2004. Ceratocystis polychroma sp. nov., a new species from Syzygium aromaticum in Sulawesi. Stud. Mycol. 50, 273-282. 